INTERDISCIPLINARIA ARCHAEOLOGICA NATURAL SCIENCES IN ARCHAEOLOGY

Thematic Review

\title{
Current Development in Archaeological Remote Sensing: A Central European Experience and Evaluation
}

\author{
Martin Gojda ${ }^{\mathrm{a}, \mathrm{b}^{*}}$ \\ anstitute of Archaeology, Praha, Czech Academy of Sciences, Letenská 4, Praha 1, Czech Republic \\ ${ }^{b}$ Institute of Archaeology, University of Cardinal Stefan Wyszyński, Wóycickiego 1/3, Warszawa, Poland
}

\section{ARTICLE INFO}

\section{Article history:}

Received: $5^{\text {th }}$ May 2019

Accepted: $7^{\text {th }}$ November 2019

DOI: http://dx.doi.org/ 10.24916/iansa.2019.2.5

Key words:

aerial archaeology

archaeological remote sensing

central Europe

internet map (geo)portals

landscape archaeology

satellite data

UAV

\section{$A B S T R A C T$}

This article offers thoughts on how current trends are changing the traditional objective of aerial prospection - prehistoric and ancient sites detection and the photographic record - into a more complex aim, namely, the integration of a variety of modern digitally-based, remote-sensing techniques applicable to archaeology into a process that focuses on the study of diachronic developments and synchronic patterns of past settlements. The author presents an evaluation of the current position of remote sensing in the study of the past, mainly from a central European (Czech) perspective, based on his long-term involvement in air survey and landscape archaeology in the Czech Republic.

\section{Introduction}

As a consequence of the collapse of communist regimes in former Warsaw-Pact countries, the early 1990s became a period in which aerial archaeology in Central-Eastern Europe began to write its own history. This article offers the present author's reflections on the these developments and changes within the field of archaeological remote sensing over the last quarter of a century, along with a personal evaluation of the current situation of the subject's methodology with an eye to the future, based on his practical involvement in systematic, long-term, aerial archaeological prospection and past landscape and settlement research.

In the history of archaeological remote sensing (ARS), the last couple of decades have brought several fundamental improvements to its methodology and datasets. These are pushing the discipline of Earth's remote sensing into the group of archaeology's most important instruments of cognitive processes. As a consequence, the crucial role of ARS in the current research and management of ancient/ historical landscapes, sites and monuments is obvious.

*Corresponding author. E-mail: gojda@arup.cas.cz
The article describes how current trends are changing the traditional objective of aerial archaeology - prehistoric and ancient site detection and photographic recording - into a much more complex aim, namely: the integration of a variety of modern digitally-based sophisticated techniques of RS that are applicable to archaeology into the study of diachronic developments and synchronic structures of components of ancient and historical landscapes and settlements. Also included below are notes on the significant role of orthophoto maps recently accessible to the general public via web portals (such as globally-based Google Earth, and many national map servers/ geoportals) and how to deal with this challenge in the context of sites and monuments research and management. The author presents an assessment of the role of ARS in the study of the past from a central European (mainly Czech) perspective.

\section{Theoretical considerations}

2.1 Detecting the unknown and seeing the context. Nondestructiveness as a modern archaeology postulate

To observe any kind of reality from a distance means to see it both as a whole and in context with its surroundings. This 
generally allows us to reflect on its complexity. This is true at least when looking at such an intricate component of the world like the Earth's surface. Its infinitely long evolution has been continually influenced by natural (geologic, climatic, biological) processes, and which human impact has then transformed from what used to be entirely natural into a cultural landscape. These processes have shaped the surface of the Earth and continuously transformed its seemingly stable and unchanging character.

The role of archaeology in contemporary Europe has shifted from the more traditional stress on investigation through the excavation of individual sites potentially rich in artefacts/structures/features towards the identification, documentation, mapping and protection of archaeological landscapes for both research objectives and public interest. This orientation corresponds well to the "landscape stream", one of the most fascinating phenomena, that has attracted recent populations, at least on a European scale. Several works summarising the academic approaches to landscape, and defining the principles of landscape archaeology, have been published since the beginning of this century (e.g., Doneus, 2013, pp.29-38; Fairclough, Møller, eds., 2008; Gojda, 2007; Darvill, Gojda, eds., 2001). This archaeological practice has been more common in Western European countries, but thanks to the increasing number of pan-European projects operating in EU schemes, and due to a certain number of large-scale, state-funded, national research projects in some post-communist countries, it has recently been spreading over this part of Europe as well. Consequently it is non-invasive methods of archaeological research which, since the turn of the $21^{\text {st }}$ century, have taken over the main role in theoretically-motivated (research) projects based on data collected from sites that are not endangered by development. This was explicitly proclaimed as a postulate in the early 1990s when the priority of non-invasive methods was stressed as a point of archaeological ethics at the Valetta Convention for the Protection of the Archaeological Heritage of Europe. Nevertheless, despite the global trends indicating a dominance of non-invasive prospection and field techniques, it is excavation that has maintained its position as the most frequently-applied archaeological method in the heart of Europe, primarily as a legally-supported response to permanent construction activities that have been continuously threatening archaeological heritage since 1990 on a vast scale.

Concerning non-invasive methods, ARS, from a historical perspective, is probably the most important. It ranks among the limited number of techniques that have made a contribution to the study and understanding of ancient and historical (medieval, post-medieval, industrial, early modern) periods of the human past. The importance of ARS integration into the study of settlement processes has been compared, for instance, to the invention of the telescope for the study of outer space. Among the methods for gathering/processing/interpreting archaeological data, RS is of high significance and is equal to radiocarbon dating, digital databases, DNA analysis and GIS. At the end of the 1960s and the early 1970s, Leo Deuel, writing about aerial archaeology in his famous book Flights into Yesterday, claimed that "...no other technical advance in archaeology has come so close to fulfilling the goal of recovering intricate cultural contexts, of glimpsing whole prehistoric landscapes, and of capturing a fabric of human existence through the flux of time" (Deuel, 1973, p.26).

\subsection{The 1990s $-2000 \mathrm{~s}$ turnaround: from aerial archaeology to archaeological remote sensing}

Recent technological development has influenced several archaeological branches, and it is clear that ARS has profited greatly from modern technology: the innovative instruments, devices and techniques invented and produced during the last three decades. It was precisely in this period that the author established aerial archaeology in Bohemia and pushed for the inclusion of this discipline in Czech archaeology. Starting from 1992/3, the position was set in the traditional Crawfordian way of aerial prospection as developed in the 1920s and as such was recently termed "observer-based/directed reconnaissance/aerial surveying" (Verhoeven, Sevara, 2016), "interpretive" (Šmejda, 2017) and "active-interpretive" (Gojda, 2017). It was based on a visual survey of the Earth's surface from a small aircraft flying at an elevation of c. 300 metres, taking photographs with three analogue, steady cameras and one video camera, navigating visually with the aid of a set of 1:50,000 paper maps, and then, finally, waiting a week or so to find out how successful the mission was after the set of films were developed and images enlarged in a commercial laboratory.

A couple of years later, an innovative process was launched that gradually changed aerial archaeology (also referred to as aerial archaeological prospection/reconnaissance/survey) into archaeological remote sensing - a group of techniques/ methods that produced a variety of remotely-sensed data and helped to process and analyse them by sophisticated (digital) procedures:

1. 1993-1995 - the arrival of GNSS/GPS for civilian use and the declassification of the USA's CORONA satellite imagery;

2. Second half of the 1990s - digital photography introduced to the global market; concerning aerial prospection it greatly simplified the photography process both on board the aircraft (only one camera needed) and after flights (immediate image processing and large-scale digital applicability);

3. 1999 - the launch of the first satellite system (IKONOS) producing images of very high (sub-metre) spatial resolution (in panchro), extremely important for the central European region with a prevalence of small features (pits and small sunken huts at buried, prehistoric and early medieval, settlements);

4. Around 2005 - free access via Google Earth to continuous (seamless) global orthophoto coverage (in the Czech Republic, the first national map server was launched at the same time, with currently accessible imagery taken in five years between 2003-2017; more details follow in the next section); 
5. 2005-2010 - the beginning of the massive application of airborne laser scanning (ALS) in European archaeology, perhaps the most revolutionary postSecond World War impact on the effective (fast, precise, 3D, digital,...) detection and mapping of our archaeological landscape heritage (this is absolutely true for at least central Europe where ancient, medieval and post-medieval ruined features are preserved as earthworks almost entirely in woodlands).

6. Late 2000s onward - intensified application of image spectrometry using air- and spaceborne, hyperspectral data and experimentation with automated (computersupervised) object (i.e. features of archaeological origin) detection from remotely sensed imagery.

There is no doubt that these innovations fundamentally changed the traditional image of aerial archaeology, which before this turnaround was - together with the rare application of early satellite imagery and aerial infrared photography (practiced before the 1990s mostly by American scholars, including in their European projects; Madry, 1987) - the exclusive method connected with the study of the (pre)historic landscape from above. The process relegated (traditional) aerial archaeology to the position of just one of several methods integrated into the archaeological remote-sensing "package". Nevertheless, it is obvious that the integration of modern (digitally-based) sophisticated techniques of ARS with additional field techniques, historical, cartographic and scientific methods/data has a chance to produce more reliable results in the cognitive process focused on the study of diachronic developments and synchronic structures of the components of past settlements and landscapes.

\subsection{The potential of remote sensing for central \\ European/Czech archaeology in the $21^{\text {st }}$ century}

The cognitive process, which in science/research strives to integrate a discipline's general level with contemporaneous technological achievements and theoretical concepts (paradigms), is never a linear one or one easy to coordinate. The current position of ARS is somewhat strange in that this was formerly a purely detection method predominantly dependent on the observational, physical and interpretative abilities of trained individuals (commonly termed aerial archaeologists), while during the last few years a fundamental change in the ARS agenda (platform) has occurred - primarily as a consequence of the rapid technological development. Today, the dependence of scholars (such as archaeologists, historical geographers, historical environmentalists/ecologists, etc.) on the aerial reconnaissance specialists' yearly cropmark "harvest" is decreasing. The ability to work with sophisticated software and digital-image data processing, particularly by the younger generation, makes it possible to incorporate air/ spaceborne data into everyday practice - both in the field and during desktop data processing. Vast collections of aerial and satellite images, both recent and archival, taken continuously over the Earth in digital format, are available in openaccessed map portals and geoportals. It is this phenomenon of free accessibility to worldwide air/spaceborne imagery that has radically shifted and, in a sense, democratised the
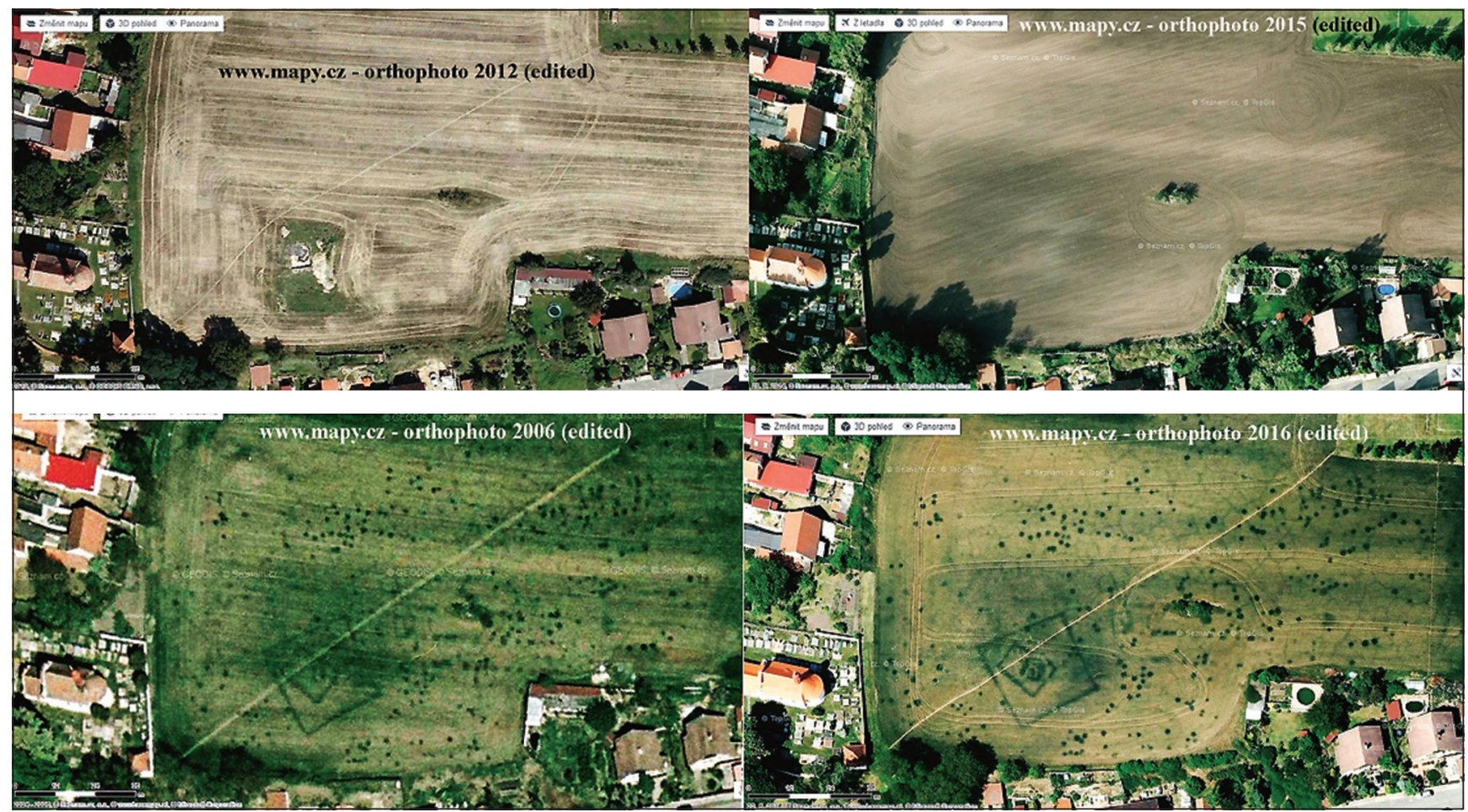

Figure 1. Orthophotos of the Ctiněves site (north-west Bohemia) from the years 2006 (bottom left), 2012 (top left), 2015 (top right) and 2016 (bottom right) as recorded on the internet map portal www.mapy.cz. Cropmarks of about 200 pits, two rectangular ditched enclosures and other structures are well recognisable on the images taken in 2006 and 2016 in the late spring. 

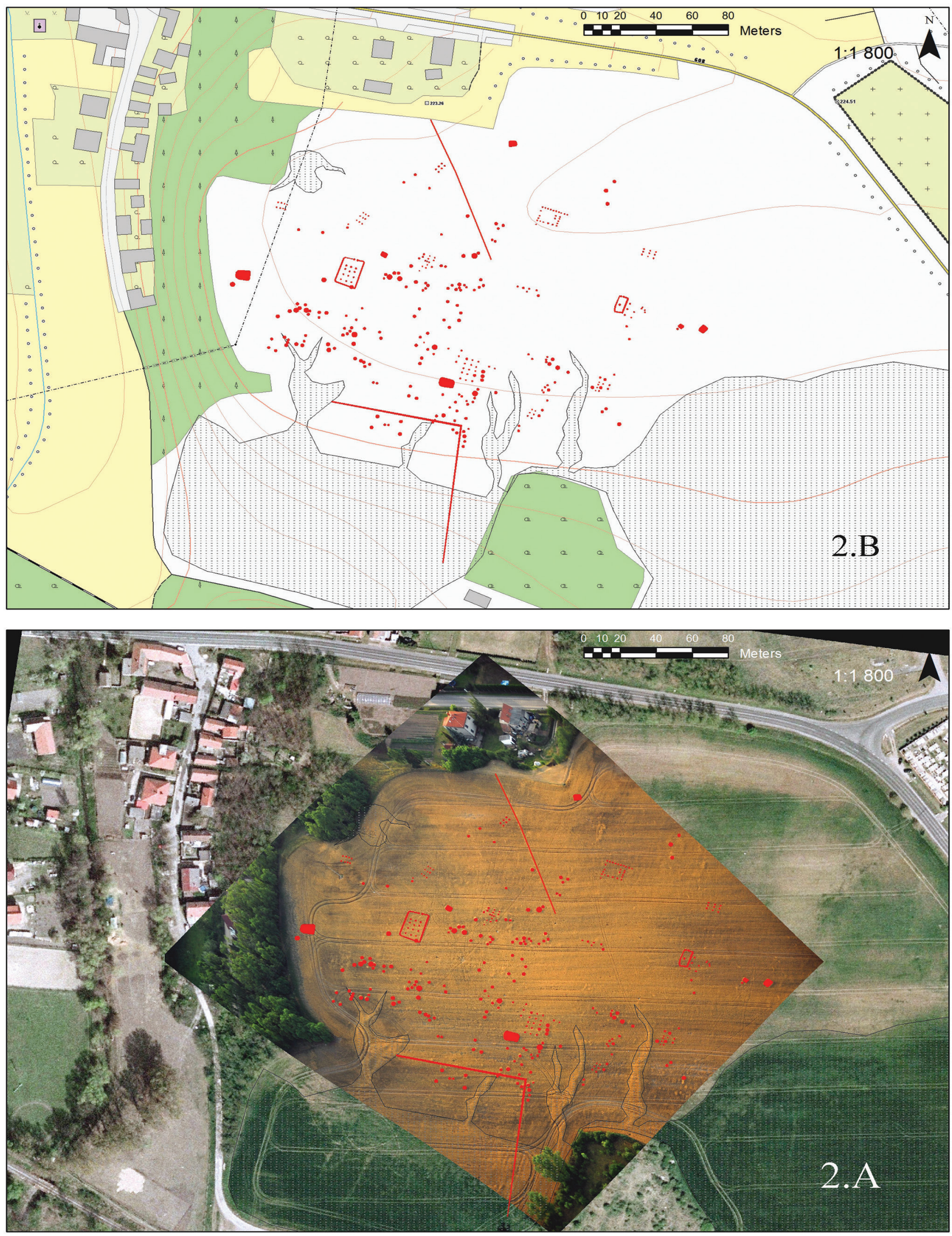

Figure 2. Straškov (northwest Bohemia): Early Iron Age settlement; (A) composition of an orthophoto (available at the map portal www.mapy.cz) and a hand-held camera image; indicated by red dots and lines are cropmark pits, two sunken houses (larger rectangular dots) and a few above-ground buildings (groups of grid-spaced tiny dots); (B) detailed plan of the site produced principally from the portal's 2006 orthophoto (a year in which the site's cropmarks were very well discernible, $c f$. Figure 1) and one almost vertical aerial photograph taken by a hand-held camera (see also Figure 5). 
originally exclusive position of aerial archaeology - not only inside archaeology academia, but among the general public. Concerning the latter, this has both positive consequences (for instance, the inspection via Google Earth and other portals of the illicit interventions and destruction of sites and monuments worldwide, e.g., Contreras, 2010; Fradley and Sheldrick, 2017; or crowdsourcing as a way of involving amateurs interested in joining the pleasure of discovery under the guidance of scholars, e.g., Duckers, 2017) and negative implications (a potential source of information for heritage looters). In this respect, a large-scale general discussion on public open access to archaeological data and on how far detailed information on absolute geographical setting (georeferencing) of buried sites are to be publicly shared must be mentioned (see a recently-issued special volume of the Czech primary heritage journal, Zprávy památkové péče - National Heritage Journal, Vol. 78/2018 focused explicitly on this problem). Great differences in the approach of European professional communities towards the general public are highly evident in the range of datasets freely accessible in national sites and monuments records.

In the context of the scale of archaeological (digital) data accessibility, it is remotely photographed ancient cropmark sites which belong among the data formats enabling easy access to their (more or less) exact location. In this respect, the existing situation in the Czech Republic has changed fundamentally: two main national internet map/geoportals with vertical seamless imagery obtained over the whole country frequently in top cropmark seasons are - in the orthophoto map format - an easy, publicly-accessible source of georeferenced traces of past human settlement activities. One of them (www.mapy.cz - retrieved $1^{\text {st }}$ May 2019) contains imagery obtained in May - July intervals in 2003, 2006 (one of two most productive years concerning the visibility of sites via the cropmark effect in the 25 -year period of 1992-2016), 2012, 2015, 2016-2017 (Figure 1). The other one (http://geoportal.cuzk.cz - retrieved $1^{\text {st }}$ May 2019) displays a set of vertical photographs acquired in 1998-2015 (usually only a section of the country was photographed, until 2002 in black and white); orthophotographic coverage of the Czech Republic at a scale of 1:5000 and historical imagery (between 1936 and the 1980s). Because up to $50 \%$ of all sites recorded this far in the country's central site and monument register (Archaeological Map of the Czech Republic, www. archeologickamapa.cz and http://digiarchiv.amapa.cz - both retrieved $1^{\text {st }}$ May 2019) are detectable on the above portals (as recently calculated by authors on a sample territory of Bohemia), no further systematic concealing of archival aerial photos with visible crop/soil-marked archaeological evidence on them is meaningful. Photos of sites in need of special protection, such as post-Neolithic flat cemeteries, ploughed-out barrows and sites connected with postmedieval military activities, all of which are most frequently threatened by illicit metal-detector hunters and, at the same time, have not been captured on images presented on the freely-accessible web orthophoto maps, are only available to scholars from accredited institutions. The potential of web portals, such as Google Earth, for the identification and evidence of unknown/unrecorded archaeological sites has been demonstrated in several projects, for instance, in the Near/Middle East (most recently e.g., Stott et al., 2018; Rayne and Donoghue, 2018). As an obvious consequence of the occurrence of so many cropmark buried sites on internet geoportals, detailed mapping of them - in conjunction with archival oblique images - is now under way (Figure 2).

\section{Bohemia: extending ARS practice in research and heritage management}

Unlike the previous period, when the Institute of Archaeology (IA) of the Czech Academy of Sciences (as the central archaeological body in the country) performed systematic aerial archaeological prospection (implemented in its research agenda in 1992) by means of traditional, lowaltitude, visual observation from institutional small aircraft (terminated in 2016), the Institute is currently switching from that method of collecting data to the application of modern RS techniques. First of all, the Institute has been operating since 2017 with two UAVs (unmanned aerial vehicles: RPAS - remotely piloted aircraft systems or drones), which serve primarily as a principal tool for the detailed recording and photogrammetric mapping of excavated sites in various stages of the fieldwork process (presently this UAV - assisted documentation method is applied by many archaeological institutions in Bohemia, especially by university departments and rescue units). Digital elevation models (DEM) produced from the data acquired in this way are used for the 3D-reconstruction of assorted features (such as houses and churches), settlements (Figure 3) and fortifications. For example, in 2018, well-developed cropmarks displaying a few buried military installations from the Napoleonic era in northwest Bohemia were photographed. The orthorectified images are now being processed and the subsequent DEM will serve as a basis for the digital reconstruction of the original earthwork structures. The model will be presented in local media and on the internet. We believe this is one of the appropriate ways of using sophisticated procedures to bring the meaning of archaeology to the public consciousness in the current digital era (Květina et al., 2015).

Another project based on the use of the Institute's UAVs is currently being prepared for its launch during next year's cropmark campaign. Prehistoric settlements and burial sites, which will be displayed through cropmarks, will be photographed (given the recent central European weather trend towards abnormally dry spring and summer seasons, the occurrence of well-developed cropmarks can be expected for at least the next few years). Orthorectified photographs will be georeferenced and transformed into a plan/map in GIS (a couple of UAV flights were tested in 2017-2018). The absolute and relative accuracy of the sites' spatial (geographical) setting will be compared to that on the internet map/geoportals. This method for the production of exact plans of archaeological sites is expected to be 


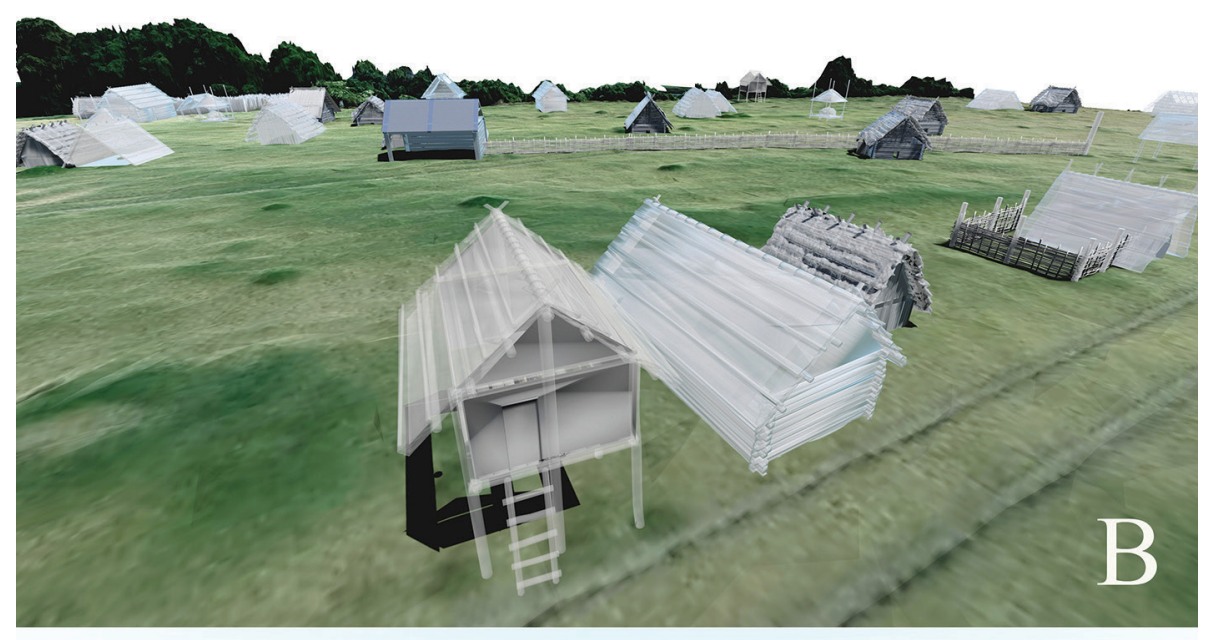

Figure 3. Račiněves (northern Bohemia). (A) DSM of a cropmark late prehistoric rural settlement produced from imagery taken over the site from UAV in June 2017 - rectangular features are sunken houses; (B) the village in a 3D reconstruction (author: J. Unger, processed in Agisoft PhotoScan and Lumion software).

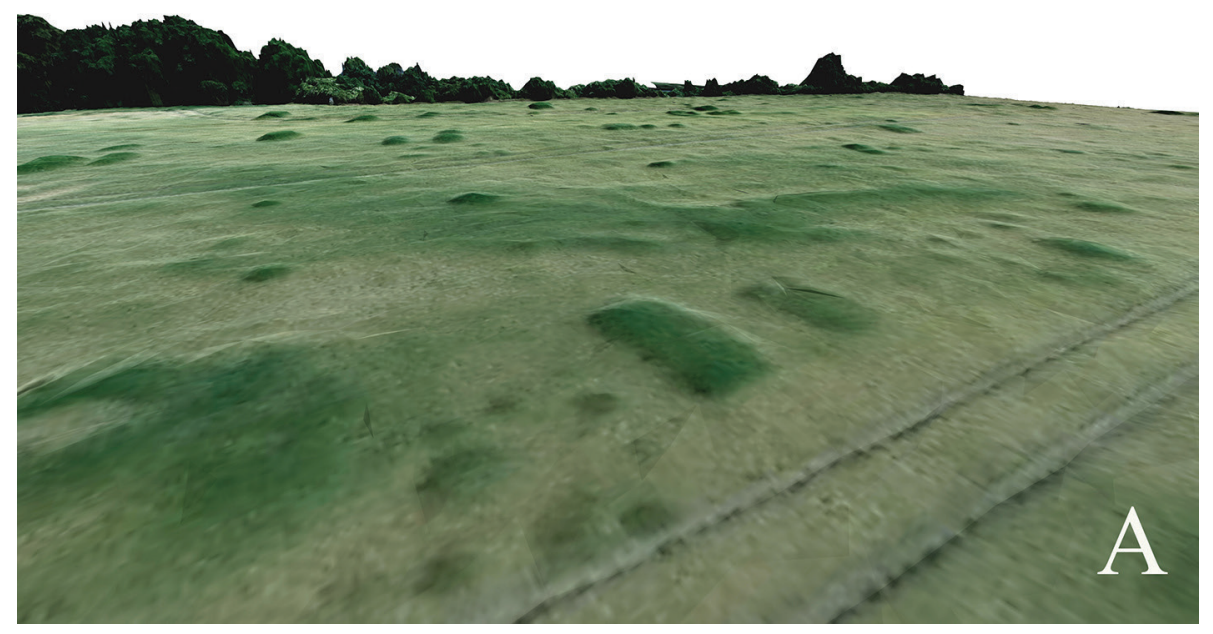

more effective than the currently-applied procedure based on manual rectification - vectorisation of oblique images. With cropmark features photographed at low altitude, the differences between the heights of plants growing over and outside them (sunken houses, pits, ditches, etc.) will be easy to measure which, among other indications, can point to their relative depth.

In close cooperation with the Czech Geological Survey, the IA instigated in 2017 a low-cost project based on the detection of ancient burials using RGB and NIR high-resolution data acquired by UAV (a multirotor-copter) over the archaeological site near Černouček, Czech Republic (Koucká et al., 2018). This site was discovered at the beginning of the 1990s as a result of low-altitude aerial reconnaissance carried out by the IA. Two ditched enclosures were identified thanks to vegetation marks in late spring and early summer - higher moisture and the presence of some chemical constituents in the secondary infill of the ditches provide better growing conditions for plants above them. In June 2017, new UAV data (Red, Green and Blue: RGB and Red and Near-infrared data: Red+NIR) were acquired over the Černouček site to determine whether there are other objects hidden under ground. Using the RGB data digital elevation models were derived, while the Red+NIR data were used to compute vegetation indices (VI), and spatial filtering, allowing the enhancement of local anomalies in the VI values, was employed. As a result, several small ringditched features, probably burials, were detected (Figure 4). In the future, we plan to acquire RGB and Red+NIR data outside of the top vegetation season, on the bare field surface, to try to learn if the composition of secondary infill of buried features is so different from the natural subsoil that it may result in its manifestation via different spectral characteristics (on the detection of buried features by these procedures, see, for example, Agapiou et al., 2013).

A generally-applicable, methodical process of semiautomatic vectorisation (currently carried out manually) of cropmarked archaeological features (recorded on orthorectified photographs) and their subsequent georeferencing in GIS software was recently proposed. It aims to simplify, improve the accuracy, and accelerate the mapping process of archaeological cropmarked sites (Figure 5); for more details see Gojda and Gojda, 2019).

Also, a note on the current preparation of a joint project of the IA and the Department of Image Processing - Institute of Information Theory and Automation (Czech Academy 
Figure 4. Černouček (northwest Bohemia): Red+NIR data were used to compute vegetation indices (VI): NDVI, Simple Ratio Index and NIR displayed as RGB. Arrows indicate small circular ditched enclosures previously not evidenced. I and II: burial enclosures well visible through cropmarks every dry spring/summer season since 1991 (Koucká et al., 2018).

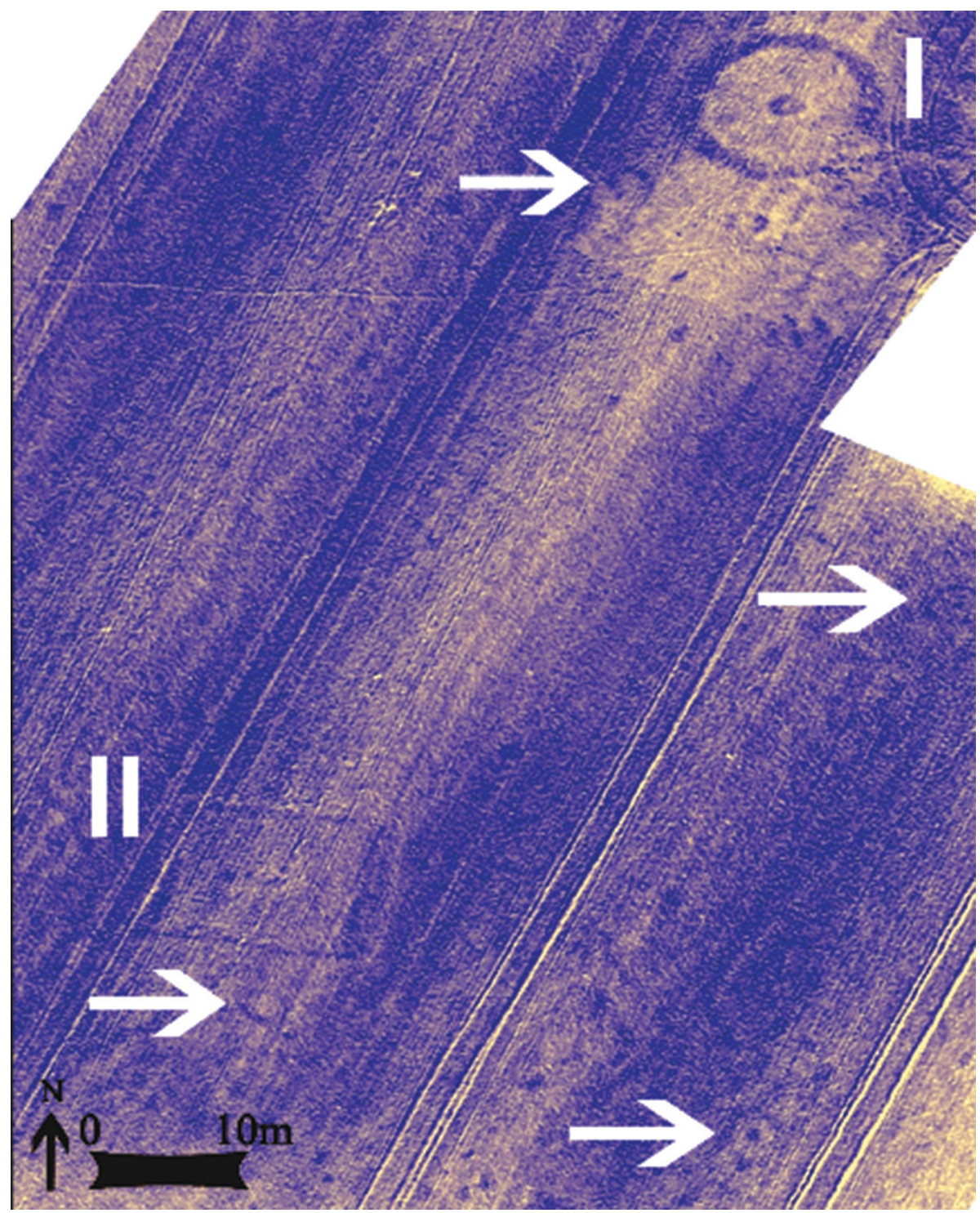

of Sciences) deserves to be mentioned. The project's objective is cooperation in the process of testing various algorithms/procedures in the (semi)automatic distinction of (geometrically) regular man-made features detectable through the cropmark effect on digital collections of aerial vertical images (orthophotographs) and satellite data. The anticipated results concern - as in similar projects of this kind elsewhere in Europe - determining the rate of the potential and effectiveness of this method for the identification of traces of past human activities hidden under the surface in large territorial units (e.g. Bennett et al., 2014; Toumazet et al., 2017).

Airborne laser/LIDAR scanning (ALS) data analysis and integration in landscape studies is also a RS technique which has attracted the attention of mostly Czech archaeologists (Figure 6; see the first continental thematic volume on the results of ALS application in archaeology projects published by the University of West Bohemia/UWB in Gojda and John, eds., 2013), and which, a few years ago, was included in the agenda of landscape archaeology seminars for students at the
University of West Bohemia (teaching practical skills in the use of software for ALS data processing). The projects are based either on data (both classified in LAS and/or ASCII formats, and in DSM/DTM format) publicly available on the internet (the coverage of the whole Czech Republic is accessible via the website of the State Administration of Land Surveying and Cadastre at ags.cuzk.cz/dmr/ - retrieved $1^{\text {st }}$ May 2019) or, occasionally, via contract scanning of selected areas under study.

\section{Conclusion}

There is no doubt that the role of remote sensing will continue to increase in the archaeological cognitive process in the $21^{\text {st }}$ century, an assumption supported by at least three factors: (1) strong persistent interest inside both academia and the general public in the landscape phenomenon; (2) the non-invasive nature of all RS techniques; (3) rapid development in information and communication technologies 
varianta $1 a \quad$ varianta $1 b \quad$ varianta $2 a \quad$ varianta $2 b$

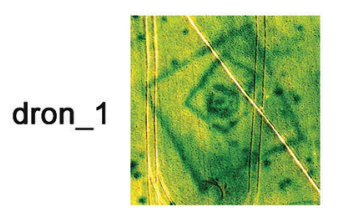

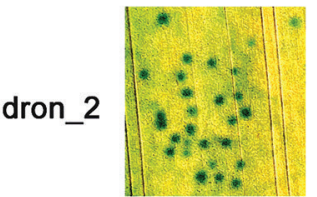

dron_3

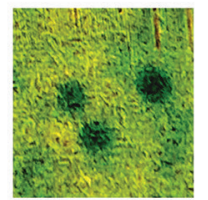

ron_4
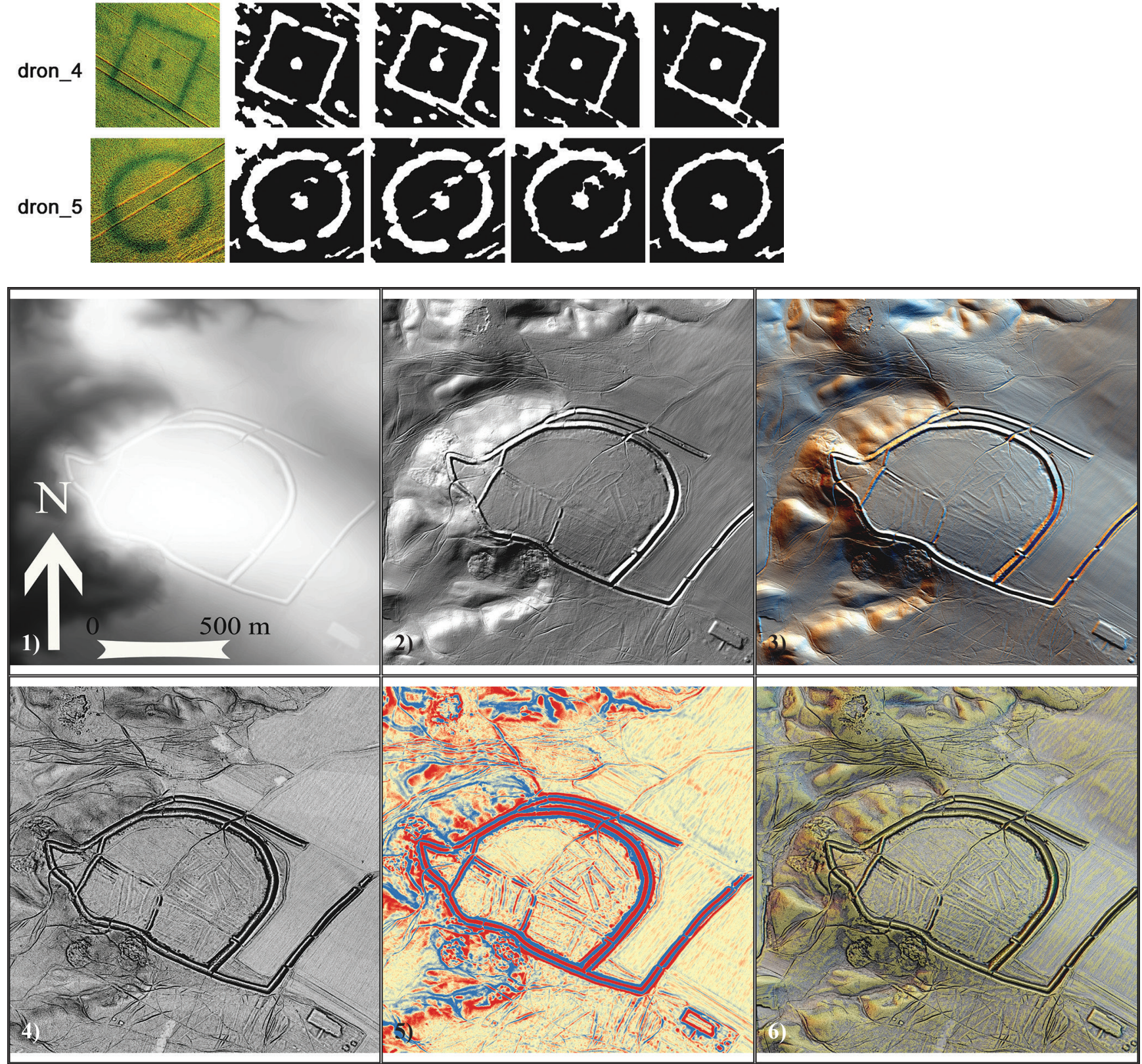

Figure 6. DTM visualisations. 3D model of the Češov hillfort (eastern Bohemia) visualised by means of various algorithms: 1) basic DEM; 2) standard hill-

shade; 3 ) shaded model illuminated from 16 places; 4) positive openness; 5) differential model; 6) blending of models 3-5 (processed by D. Novák, IA).
Figure 5. The application of four pre-processing variants on assorted prehistoric features photographed from a drone (author: O. Gojda).

\section{.}
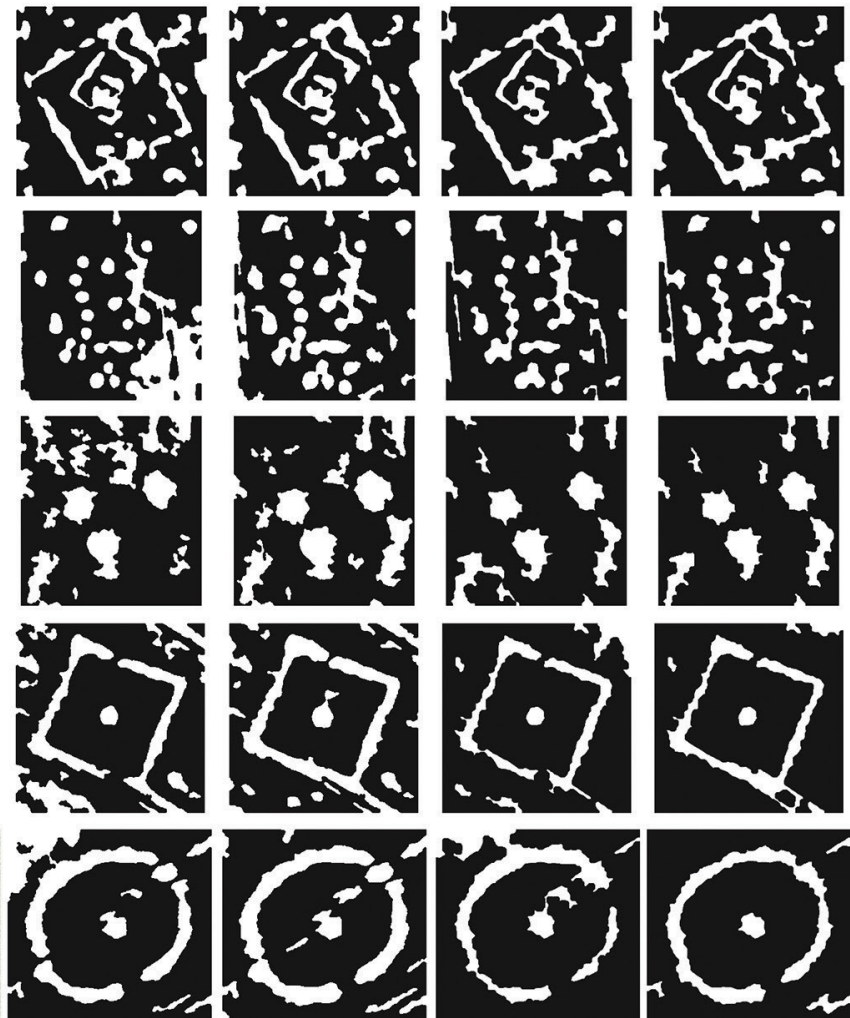
and in digital image data acquisition and processing, whose hi-tech products meet the current needs of earth sciences, including (past) landscape research. The permanent process of the miniaturisation of cameras and scanners for optical and ALS data acquisition on the one hand, and simultaneous progress in the operational abilities of UAVs on the other, have been acting towards the wide-spread application and inclusion of remotely-sensed data in current and future archaeological landscape and settlement projects.

As noted above, in addition to the important role of ARS in research, its irreplaceable role in heritage management (the monitoring and recording, from above, of the actual state of standing sites and architectural monuments, urban units, ancient earthworks, etc.) and the detailed documentation and mapping of (especially large) sites in the process of excavation will certainly be significant.

Another potentially important aspect of ARS, namely its ability to raise and resolve theoretical questions, should also be taken into account. As archaeological remote survey is not just a set of prospection methods used in advance of excavation but an autonomous discipline with its own approach to understanding archaeological data, it usually represents an inseparable part of research on regional histories, settlement dynamics, in the identification of nodal points in prehistoric settlement networks, and for the analysis of relationships between sites. The potential of ARS for resolving these issues is often crucial in the sense that data collected via ARS methods are of such a nature (particularly in terms of quantity and variability) that they could not be assembled in certain environments (for example, on fully-formed river terraces or on shallow chalk deposits) using any other method.

However, a couple of points concerning the future development of ARS need to be considered. One of them is whether the traditional RS method - aerial prospection from small aircraft flying at a low altitude - should be currently (and in the future) continuously applied at the same intensity as it has been since its pioneering times a century ago. For many reasons, a recent critique (Verhoeven and Sevara, 2016, chapter 1) of the persistent primary use of this method is understandable and acceptable. In the era of fully automatic air/spaceborne flying vehicles (manned as well as remotely-controlled) and special hi-tech cameras/scanners, this old-fashioned way of ARS seems to be perhaps the last remnant of those romantic times when archaeology started turning away from its antiquarian image towards a discipline giving itself a more scientific facelift. Nevertheless, situations may occur, at least in the near future (such as an urgent need for the immediate prospection and recording of cropmark sites over a territory too large for meaningful application of UAVs, or a demand for making in a limited time span an aerial photographic record of several dozen monuments, castles, palaces, monasteries, gardens/ parks, villages, etc., spread across a vast area), when hardly any alternative would be able to substitute this method. Someone could also point to the limited capacity of common archaeological institutions to acquire special hardware/ software, data (such as current, very high-spatial/spectralresolution, satellite images) and the technical instruments necessary for a meaningful ARS application. In principle, this problem is a general one in science and research, but it is necessary to emphasise that the cost of the technical tools useful for ARS is continually decreasing: to buy a good standard UAV equipped with a common camera, or archival spaceborne data, is now affordable even for institutions with relatively low operation funding.

\section{Acknowledgements}

This work was produced in the framework of the project Archaeological Information System of the Czech Republic - second generation (AIS-2), reg. No. CZ.02.1.01/0.0/0.0/1 6 013/0001439 administrated by the Ministry of Education, Youth and Sports inside the EU operational programme Research, Development and Education.

\section{References}

AGAPIOU, A., HADJIMITSIS D.G., SARRIS, A., GEORGOPOULOS, A., ALEXAKIS, D., 2013. Optimum temporal and spectral window for monitoring crop marks over archaeological remains in the Mediterranean region. Journal of Archaeological Science, 40, 1479-1492.

BENNETT, R., COWLEY, D., DE LAET, V., 2014. The data explosion: tackling the taboo of automatic feature recognition in airborne survey data. Antiquity, 88, 896-905.

CONTRERAS, D.A., 2010. Huaqueros and remote sensing imagery: assessing looting damage in the Virú Valley, Peru. Antiquity, 84, 544-555.

DARVILL, T., and GOJDA, M., eds., 2001. One Land, Many Landscapes. Oxford: British Archaeological Reports Int. series 987.

DEUEL, L., 1973. Flights into Yesterday. The Story of Aerial Archaeology. Harmondsworth: Penguin Books.

DONEUS, M., 2013. Die hinterlassene Landschaft - Prospektion und Interpretation in der Landschaftsarchäologie. Mitteilungen der Prähistorischen Kommission, Band 78. Wien: Verlag der Österreichischen Akademie der Wissenschaften.

DUCKERS, G.L, 2017. Bridging the „geospatial divide"in archaeology: community based interpretation of lidar data. [online]. Available from: http://intarch.ac.uk/journal/ issue35 (retrieved $28^{\text {th }}$ April 2019).

FAIRCLOUGH, G.J., and MØLLER, P.D., eds., 2008. Landscape as Heritage - The Management and Protection of Landscape in Europe. Berne: University of Berne.

FRADLEY, M., and SHELDRICK, N., 2017. Satellite imagery and heritage damage in Egypt: a response to Parcak et al. (2016). Antiquity, 91, 784 792.

GOJDA, M., 2007. Landscape Archaeology. In: Hardesty, D.E., ed., Encyclopedia of Life Support Systems - Archaeology 1, 198-226. UNESCO and Oxford: Eolss Publishers.

GOJDA, M., 2017. Archeologie a dálkový průzkum. Historie, metody, prameny - Archaeology and Remote Sensing. History, Methods, Data. Prague: Academia.

GOJDA, M., and GOJDA, O., 2019. Mapování a návrh částečně automatizované vektorizace sídelních aktivit $\mathrm{z}$ dat dálkového archeologického průzkumu v prostředí GIS - GIS-based mapping and a proposal for semiautomatic vectorisation of settlement activities from archaeological remote sensing data. Archeologické rozhledy (in press).

GOJDA, M., and JOHN, J., eds., 2013: Archeologie a letecké laserové skenováni krajiny - Archaeology and Airborne Laser Scanning of the Landscape. Plzeň: University of West Bohemia.

KOUCKÁ, L., KOPAČKOVÁ, V., FÁROVÁ, K., GOJDA, M., 2018. UAV mapping of an archaeological site using RGB and NIR high-resolution 
data. Sciforum Electronic Conference Series, Vol. 2. Available at: https:// sciforum.net/conference/ecrs-2 (accessed 28th April 2019).

KVĚTINA, P., UNGER, J., VAVREČKA, P., 2015. Presenting the invisible and unfathomable: Virtual museum and an augmented reality of the Neolithic site in Bylany, Czech Republic. Archeologické rozhledy, 67(1), $3-22$.

MADRY, S., 1987. A multiscalar Approach to Remote Sensing in a Temperate Regional Archaeological survey. In: Crumley, N., Marquardt, W., eds. Regional Dynamics: Burgundian Landscape in Historical Perspective. 173-235. San Diego: Academic Press.

RAYNE, L., and DONOGHUE, D., 2018. A remote sensing approach for mapping the development of ancient water management in the Near East. Remote Sensing, 10, 2042. doi: 10.3390/rs10122042.
STOTT, D., KRISTIANSEN, S.M., LICHTENBERGER, A., RAJA, R., 2018. Mapping an ancient city with a century of remotely sensed data. [online], Proceedings of the National Academy of Sciences. Available from: w.ww.pnas.org/cgi/doi/10.1073/pnas. 1721509115 (retrieved 28 $8^{\text {th }}$ April 2019)

ŠMEJDA, L., 2017. Interpretive and Analytical Approaches to Aerial Survey in Archaeology. Interdisciplinaria Archaeologica - Natural Sciences in Archaeology, 8(1), 79-92.

TOUMAZET, J.P., VAUTIER, F., ROUSSEL, E., DOUSTEYSSIER, B., 2017. Automatic detection of complex archaeological grazing structures using airborne laser scanning data. Journal of Archaeological Science: Reports, 12, 569-579.

VERHOEVEN, G., and SEVARA, C., 2016. Trying to break new ground in aerial archaeology. Remote Sensing, 8, 918. doi:10.3390/rs8110918. 